\title{
VIŠJA ŠOLA ZA POSLOVNE SEKRETARJE NA DALJAVO
}

\section{Izobraževanje prek interneta kot nova možnost izobraževanja odraslih $v$ Sloveniji}

\section{IZOBRAŽEVANJE ODRASLIH IN SODOBNA TEHNOLOGIJA}

$\mathrm{S}$ splošnim razvojem gre z roko $\mathrm{v}$ roki tudi izobraževanje odraslih, ki se v praksi nenehno prilagaja spremembam in novostim ter je $\mathrm{v}$ zadnjih desetletjih $\mathrm{v}$ teoriji in praksi zelo napredovalo. Vzrokov je prav gotovo več: splošni tehnološki razvoj, skupaj z razvojem komunikacijskih možnosti, spremembe v strukturi dela (odmiranje nekaterih poklicev, pojav novih, pojav brezposelnosti ipd.), spremembe v razmerjih družbenih sektorjev (v razvitih družbah je vse večji delež terciarnega in kvartarnega sektorja), nenehna potreba po pridobivanju, nadgrajevanju in dopolnjevanju znanja na vseh delovnih mestih (teorija vseživljenjskega učenja je danes realnost).

Pod temi pogoji in skupaj z njimi se razvija tudi izobraževanje odraslih, saj se je njegova praksa v svojih temeljih ves čas prisiljena prilagajati sodobnim tokovom, potrebam ljudi ter spremembam delovnih področij.

Praksa izobraževanja odraslih tako z uvajanjem novosti vnaša v učni in izobraževalni proces tudi sodobne tehnične pridobitve ter prav zato pogosto spodbuja splošni napredek v poučevanju in šolstvu. Izobraževalci so pri posebnostih izobraževanja odraslih vedno pred novimi izzivi, kako učenje in izobraževanje čimbolj prilagoditi značilnostim odraslih (in v okviru te skupine posameznim ciljnim skupinam), da bodo uspešni in si bodo pridobili čimbolj uporabno znanje za življenje in delo.
Znanje v dobi informatike dobiva povsem novo razsežnost, saj gre za poplavo informacij in znanja, ki ga drugače kot doslej urejamo v logično povezane zveze. Trenutno lahko trdimo, da jih najbolj globalno zajema internet sodobni dosežek komunikacijske tehnologije, ki ponuja skoraj neomejene razsežnosti iskanja, spoznavanja in vedenja. Ne samo to, posebno vlogo mu daje možnost interakcije med njegovimi uporabniki.

Že s samim pojavom in širitvijo razsežnosti izobraževanja odraslih se v skladu s sodobnimi tokovi pojavlja tudi vpletanje tehničnih pridobitev in tehnološkega razvoja $\mathrm{z}$ novimi komunikacijskimi možnostmi. Tudi zato imamo opravka s spremenjenim odnosom med učiteljem in učencem oziroma tistim, ki sam proces usmerja, in tistim, ki je vanj vstopil prostovoljno. Lahko govorimo tudi o bolj razločnem prepoznavanju notranje motivacije za učenje in bolj transparentnem dokazovanju, da učenje nima meja. Sodoben razvoj v učenju in izobraževanju kaže na večjo vključenost posameznika v oblikovanje vsebin in načina učenja ter zagotavljanje doseganja učnega uspeha le $\mathrm{z}$ njegovo aktivno vlogo. Pojav interneta v izobraževanju je to še povečal.

Povzete značilnosti tradicionalnega načina izobraževanja v razredu, učilnici, predavalnici in učenja prek interneta oziroma »on-line « nazorno dokazujejo prevladovanje kognitivnega učenja $v$ novi razsežnosti učenja, ki bo 
po napovedih strokovnjakov s tega področja $\mathrm{v}$ 21. stoletju pomenilo polovico vsega učenja in izobraževanja (Draves, 2000).

Značilnosti izobraževanja na daljavo

1. Pomeni novo možnost izobraževanja, dostop do izobraževanja večjemu številu ljudi, ki so imeli doslej slabše možnosti zaradi geografske oddaljenosti.

2. Pomeni največjo možnost prilagajanja učenja lastnim časovnim potrebam udeležencev doslej, saj si lahko sami razporejajo čas v dnevu, ki ga namenijo učenju ali študiju, saj niso vezani na organizirane oblike, pri čemer se je treba udeležiti srečanja na določenem kraju ob določenem času ponujena možnost izobraževanja tudi zelo zaposlenim, prav zato lahko govorimo o visoki stopnji fleksibilnosti.

3. Pomeni povečanje možnosti za kulturni, ekonomski in socialni razvoj oddaljenih geografskih območij (Bregar, 1998).

4. $\mathrm{Z}$ odpiranjem novih poti do različnih virov znanja zaradi vnašanja sodobnih tehnologij $\mathrm{v}$ učni proces se spreminja tradicionalna vloge učitelja; »učitelj vse bolj postaja metodolog za pridobivanje informacij in za njihovo učinkovito spreminjanje v znanje « (Bregar, 1998).

5. Z uvajanjem novih tehnologij v izobraževanje in navezovanjem stikov ter komunikacijo med študenti vnaša več skupinskega dela (Bregar, 1998).

6. Gre za nenehno vnašanje inovacij v učni proces in stalno raziskovanje pedagoškega in andragoškega procesa, kar pomeni nenehno izpopolnjevanje pedagoških in andragoških delavcev (Bregar, 1998).

7. Ker se vsak posameznik uči drugače, lahko pri tej obliki izobraževanja skoraj vsak sodeluje z lastnim načinom, saj se sistem najbolj prilagaja značilnostim posameznika, še posebej, ker so pogosto na voljo različen učni material in različni viri.
Poleg naštetih značilnosti se $\mathrm{v}$ primerjavi $\mathrm{s}$ tradicionalnim načinom $\mathrm{v}$ učnem procesu izobraževanja »on-line « pojavljajo še nekatere posebnosti:

- Zahteva pretežno pisno komuniciranje in nagnjenost $\mathrm{k}$ pisnemu sporočanju ali pa vsaj več.

- Pomeni manj možnosti, da se oddaljimo od teme diskusije in cilja vsebine, ki jo obravnavamo, kot pri klasičnem, razrednem delu.

- Zahteva višjo stopnjo samodiscipline (dnevni čas učenja si vsakdo načrtuje sam, prav tako opravljanje nalog) in samostojno delo.

- Zahteva določeno stopnjo računalniške pismenosti.

- Povratne informacije tutorja oziroma mentorja niso takojšnje (razen pri videokonferenci ali v klepetalnicah), prihajajo $\mathrm{z}$ zamudo.
Vse večje potrebe po znanju ne moremo več zadovoljiti les klasičnim načinom izobraževanja.
- Študentje imajo čas za premislek pri odgovorih oziroma opravljanju nalog.

- Proces učenja po Bloomovi taksonomiji pogosteje kot pri tradicionalnem načinu presega nižje ravni, pomeni višje miselne procese in boljšo učinkovitost izobraževanja.

- Ustreza nekaterim ljudem, ne pa vsem (odvisno od učnega stila).

\section{IZKUŠNJJE Z IZOBRAŽEVANJEM NA DALJAVO V SVETU IN DOMA}

Z izobraževanjem na daljavo imajo domače in tuje ustanove različne izkušnje, tudi z različnimi načini študija na daljavo.

Najbolj znane univerze po svetu, ki imajo že kar tradicijo in tudi sloves $\mathrm{z}$ izobraževanjem na daljavo, so: Open University iz Velike Britanije (tudi najstarejša in najnaprednejša $\mathrm{v}$ zgodovini razvoja študija na daljavo), sicer pa med zelo znane spadajo univerza $v$ Hagnu $v$ 
Nemčiji, Uivesidad Nacional de Educatión Distancia v Španiji (Bregar, 1998). Poleg teh se pojavljajo tudi zasebne ustanove in velika podjetja, ki organizirajo različne oblike izobraževanja na daljavo. V Sloveniji ima za zdaj največ izkušenj in uspehov Ekonomska fakulteta v Ljubljani s svojim izobraževanjem na daljavo po programu Visoke poslovne šole, sicer pa se v posameznih segmentih izobraževanja na daljavo lotevajo tudi druge fakultete v Sloveniji. Pri posameznih predmetih na različnih fakultetah na Univerzi $\mathrm{v}$ Ljubljani nekateri profesorji že uporabljajo virtualne možnosti na tako imenovani virtualni univerzi, ki je začela aktivno delovati v prejšnjem šolskem letu.

Mnoge univerze po svetu že uvajajo izobraževanja na daljavo, vendar so tudi drugje tradicionalni izobraževalni sistemi dokaj nenaklonjeni sprejemanju novih izzivov tehnološkega napredka (Bregar, 1998). Tudi po svetu, tako kot pri nas, ugotavljajo, da se univerzitetni sistemi na nove načine tě̌ko prilagajajo oziroma ga redko uvajajo. Mnogo večji odziv in pripravljenost na organizacijo takega izobraževanja pri nas in po svetu so pokazala podjetja in zasebne izobraževalne ustanove, vsekakor pa bolj področje izobraževanja odraslih kot izobraževanje otrok in mladine oziroma redni šolski sistemi.

Včasih so med oblike izobraževanja na daljavo uvrščali dopisno izobraževanje, vendar to danes po mnenju znanih strokovnjakov več ne velja. Sedanje pojavne oblike izobraževanja na daljavo namreč vključujejo najrazličnejše načine medsebojnega komuniciranja, torej gre za interakcijo med udeleženci in tutorjem/mentorjem, pa tudi med samimi udeleženci izobraževanja. Še posebej je pomembno, da študenti komunicirajo med seboj, česar »staro« dopisno izobraževanje ni poznalo. Sodoben način izobraževanja na daljavo je zaradi tehničnih pridobitev mnogo pestrejši in zanimivejši, tudi bolj prilagodljiv različnim učnim tipom. Njegova prednost je $\mathrm{v}$ različnih načinih posredovanja učne vsebine. Tako se pojavljajo najrazličnejše kombinacije komunikacije in aktivnosti, ki jih pripravljalci in organizatorji izobraževanja na daljavo vpletajo v izvedbo programa.

Prav zaradi vzpostavljanja interakcije se $\mathrm{v}$ današnjem izobraževanju na daljavo uporabljajo različne možnosti za pomoč udeležencem pri predelavi učnih vsebin. Razdelimo jih lahko po enostavnosti in dodatnem razvoju:

1. Učbeniki z dopisanimi, tako imenovanimi vodiči za samostojno predelavo vsebin.

2. Učbeniki za samostojno učenje (posebej napisani in s primeri ter vajami), lahko so tudi podprti $\mathrm{z}$ avdio ali video posnetki.

3. Redna tedenska ali štirinajstdnevna srečanja udeležencev s tutorjem/mentorjem, za krajše predstavitve zelo zahtevnih vsebin, pojasnjevanje opravljenih nalog in tudi za pojasnjevanje nejasnosti pri sprotnih vsebinah, če gre za daljše oblike študija.

4. Predavanja, ki jih oddaljeni udeleženci poslušajo in lahko tudi sodelujejo v njim najbližjem študijskem centru, prek tako imenovanega video konferenčnega sistema.

5. Učenje $s$ pomočjo računalnika in $\mathrm{CD}$ ROM-ov, pri čemer udeleženci namesto knjižnega zapisa uporabljajo zapis na CDROM-ih, ki pogosto ponuja več možnosti aktivnega vključevanja udeležencev kot knjižni zapis ali posnetki na avdio in video kasetah.

6. Izobraževanje »on-line«, pri čemer posebej pripravljeni programi na internetu ponujajo najrazličnejše možnosti komunikacije in študija. Do teh programov je mogoče priti prek spletnih strani ustanov, ki ponujajo izobraževanje, in s pomočjo uporabniških imen in gesel, ki jih prejmejo vsi prijavljeni v izobraževalni program. Izobraževanje najpogosteje poteka na podlagi tako imenovanih konferenc (področja in vrste informacij ter vsebin, ki jih ponujajo, na primer koledar, študijske vsebine po predmetih, lastni zapiski, klepetalnica ipd.). Pogosta 


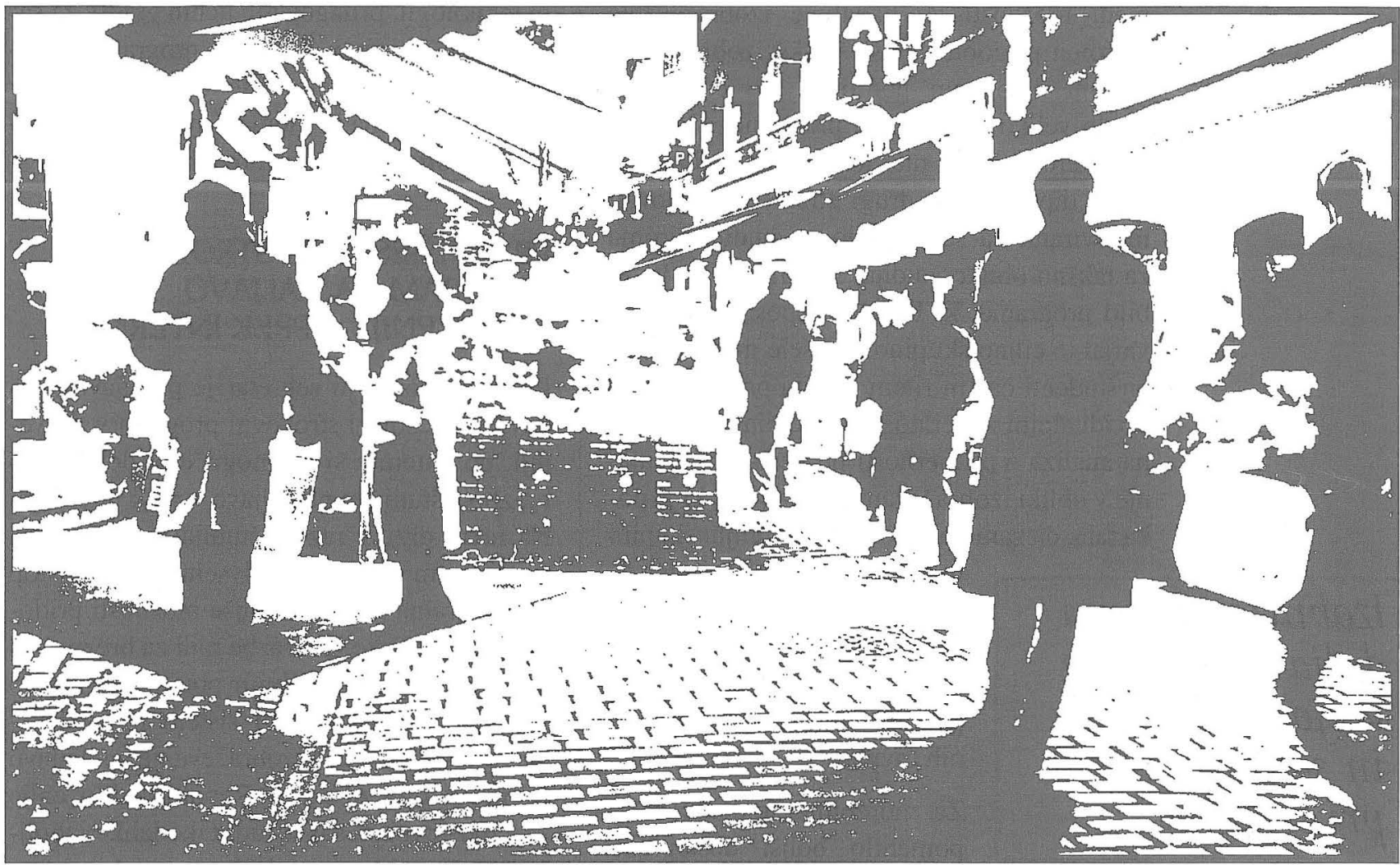

kombinacija izobraževalnih programov prek interneta je tudi komunikacija prek elektronske pošte, pri čemer si študenti in njihov tutor/mentor izmenjujejo naloge, mnenja, izkušnje ipd. in tudi komunicirajo med seboj. Izobraževalnim programom na internetu pa $\mathrm{v}$ zadnjem času dodajajo tudi tako imenovani računalniško podprt video konferenčni sistem, pri katerem ni več potreben obisk študijskega centra kot pri klasičnem video konferenčnem sistemu, ampak udeleženci izobraževanja sodelujejo kar doma. Zato pa seveda potrebujejo ustrezno računalniško opremo.

Vsem navedenim možnostim je skupno, da so namenjene udeležencem, ki naj bi tako čim učinkoviteje osvajali učno snov. Od področja študija, splošne tehnične opremljenosti udeležencev oziroma ciljne skupine, pa tudi organizacijske strukture študija in kadrovske ter tehnične opremljenosti ustanove, ki izobraževalni program organizira, je odvisno, katero kombinacijo možnosti posredovanja vsebin in komunikacije s študenti bo izbrala.

\section{OD ZAMISLI DO REALIZACIJE - PROGRAM POSLOVNI SEKRETAR NA DALJAVO}

Ideja o razvoju študija na daljavo se je pravzaprav rodila že med pripravo višješolskega strokovnega programa Poslovni sekretar, dozorela pa je leta 1998 , ko smo na zavodu za izobraževanje Doba v Mariboru ustanovili Višjo strokovno šolo za poslovne sekretarje in v študijskem letu 1999/2000 prvi začeli izvajati novi višješolski strokovni program Poslovni sekretar. Tipična ciljna skupina za izobraževanje na daljavo se je ponujala kar sama: to so bili večinoma zaposleni, ki imajo zaradi družinskih in službenih obveznosti 
manj možnosti za nadaljnje izobraževanje oziroma pridobitev višješolske izobrazbe na svojem delovnem področju. Po eni strani imajo veliko izkušenj in praktičnega znanja, za katero bi želeli tudi formalno potrdilo oziroma diplomo, po drugi strani pa so dovolj motivirani, da se odločijo za študij oziroma za takšno obliko študija, saj pri nas doslej ni bilo programa, ki bi tako neposredno nagovarjal to ciljno skupino, kaj šele možnosti, da bi študenti čas in ritem študija prilagajali individualnim značilnostim. Sledila je strokovna analiza o primernosti programa za izvajanje v obliki izobraževanja na daljavo, ki je pokazala, da zanimanje obstaja pri ciljni skupini

Izobraževanje na daljavo omogoča vecjo dostopnost in samostojnost pri študiju. in tudi pri delodajalcih ter da je program smiselno razviti tudi za izobraževanje na daljavo, saj bi to pomenilo vrsto pozitivnih učinkov na različnih ravneh.

Za morebitne študente bi to pomenilo boljši dostop do programa Poslovni sekretar, boljše možnosti za izobraževanje, možnost uporabe novih medijev in tehnologij, večjo samostojnost pri študiju, večjo svobodo kraja, časa in tempa študija ter možnost prilagajanja študija njihovim obveznostim. Tako bi si lahko več ljudi pridobilo višješolsko izobrazbo in konkurenca na trgu delovne sile bi se povečala. To bi omogočalo delodajalcem, da izberejo najboljši kader. Za delodajalce, ki bi želeli vlagati v izobraževanja svojega kadra, pa bi to pomenilo tudi manj stroškov za (so)financiranje študija, saj bi plačali samo šolnino, pri tem pa jim ne bi bilo treba iskati nadomestila za čas odsotnosti zaposlenega $\mathrm{z}$ delovnega mesta, saj je študij na daljavo vezan na prosti čas, zaposlenemu torej ni treba obiskovati predavanj ali vaj, ki bi utegnila biti med njegovim delavnikom.

To velja tudi za sam program Poslovni sekretar, saj lahko z vključevanjem novih medijev in tehnologij, prilagojenih učnih gradiv za samostojno učenje $\mathrm{v}$ izvajanje programa povečamo kakovost tudi tradicionalnemu načinu študija programa in s tem primerljivost $\mathrm{z}$ izvajanjem sorodnih programov v tujini.

\section{PRVI VIŠIEŠOLSKII STROKOVNI PROGRAM NA DALJAVO V SLOVENIII - PREK INTERNETA}

Program Poslovni sekretar je prvi javno veljavni višješolski strokovni program v Sloveniji, po katerem si bo mogoče pridobiti izobrazbo s študijem na daljavo - prek interneta. Na ravni države razvoj študija na daljavo za ta program pomeni predvsem boljši dostop do programa in s tem boljše možnosti pridobitve višješolske izobrazbe tudi za brezposelne, ki se zaradi posebnih potreb ne morejo vključiti $\mathrm{v}$ tradicionalni sistem izobraževanja. S tega vidika je izobraževanje na daljavo zanimivo tudi za Zavod Republike Slovenije za zaposlovanje, saj bi tudi tako lahko izboljšali možnosti brezposelnih za pridobitev formalne izobrazbe in njihovo vlogo na trgu dela. $\mathrm{S}$ tem bi pripomogli $\mathrm{k}$ zmanjševanju strukturne brezposelnosti na področju pisarniškega poslovanja in spodbujanju potreb po izobraževanju ter $\mathrm{k}$ promociji vseživljenjskega učenja. Zaradi tega in splošne naklonjenosti do razvoja izobraževanja na daljavo v Sloveniji oziroma uvajanja novosti v izobraževanje so naši ideji prisluhnili tudi na Ministrstvu za šolstvo in šport ter Ministrstvu za delo, družino in socialne zadeve, ki bosta posamezne faze projekta finančno podprli. Veliko koristnih informacij in usmeritev smo dobili tudi na Univerzi, predvsem na ljubljanski Ekonomski fakulteti. Na Centru za poklicno izobraževanje so nam svetovali $\mathrm{v}$ zvezi $\mathrm{z}$ možnostjo prijave v programe Evropske unije, predvsem Socrates in Leonardo, katerih posamezna področja so namenjena sofinanciranju mednarodnih projektov, povezanih z uvajanjem novosti v izobraževanje in nadalj- 
njim razvojem poklicnega ter strokovnega izobraževanja.

\section{IZBIRA MODELA ŠTUDIJA NA DALJAVO}

Treba je bilo izbrati takšen model študija na daljavo, ki je v skladu z mednarodnimi usmeritvami na področju izobraževanja na daljavo in s tem tudi $\mathrm{z}$ vključevanjem novih medijev ter tehnologij v izobraževanje, ki je fleksibilen, primeren za potencialno ciljno skupino, upošteva domače izkušnje in temelji na rezultatih interne evalvacije izvajanja programa Poslovni sekretar v tradicionalni obliki. Pri tem smo izrabili prednost, ki smo jo kot avtorji in prvi izvajalci programa $\mathrm{v}$ Sloveniji imeli: dobro poznavanje programa nam je omogočilo, da smo s predavatelji na Višji strokovni šoli pripravili učne načrte za izvajanje sodobnega, aktivnega študija. Učno gradivo $\mathrm{z}$ elementi samostojnega učenja za prvo generacijo študentov tradicionalnega študija se je izkazalo za dobrega pokazatelja primernosti in učinkovitosti izbranega načina izvajanja študijskega programa, zato smo model izobraževanja na daljavo iskali na področju izobraževanja »on-line«. Pri iskanju modela so imele odločilno vlogo tudi mednarodna usmerjenost zavoda Doba in mednarodne izkušnje vodstva ter strokovnih sodelavcev. Pozimi leta 1999 je projekt začel dobivati svojo končno podobo, nekatere aktivnosti pa so začele potekati še pred tem, na primer analiza kadrovskih in izobraževalnih potreb po izobraževanju na daljavo v programu Poslovni sekretar ter izobraževanje strokovnih delavcev za organiziranje študija na daljavo.

\section{ANKETIRANJE POTENCIALNE CILJNE SKUIPINE}

Rezultati anketnega vprašalnika so presegli naša pričakovanja in na podlagi analize smo se lahko izognili začetni dilemi $v$ zvezi $\mathrm{z}$
$V$ tem prispevku predstavljamo povzetke rezultatov ankete o pogledih potencialne ciljne skupine na izobraževanje na daljavo. Izvedli smo jo decembra 1999 s pomočjo revije Tajnica. Anketirali smo 427 zaposlenih na področju pisarniškega poslovanja in dobili smo te odgovore: 97 odstotkov jih meni, da je za njihovo delo v pisarni potrebna višja izobrazba, in kar 93 odstotkov bi se jih odločilo za študij na daljavo. Med razlogi za študij na daljavo navajajo: na prvem mestu so anketirani navedli družinske razloge ( 24 odstotkov), sledita oddaljenost ( 23 odstotkov) in večja časovna fleksibilnost ( 23 odstotkov). Na tretjem mestu so službene obveznosti (21 odstotkov), nekateri so kot razlog navedli možnost večje samostojnosti pri študiju ( 8 odstotkov). Na vprašanje, ali imajo doma osebni računalnik, jih je 68 odstotkov odgovorilo pritrdilno, kar 99 odstotkov pa jih ima osebni računalnik v službi. $Z$ internetom je povezanih 83 odstotkov vprašanih.

vključevanjem interneta $\mathrm{v}$ izobraževanje na daljavo. Veliko zanimanje za pridobitev višješolske izobrazbe na daljavo, visoka stopnja računalniške pismenosti in dostop do interneta so bili zagotovilo, da $\mathrm{z}$ novimi mediji in tehnologijami ne ožimo ciljne skupine in ne zmanjšujemo dostopnosti do programa, ampak prav s tem načinom spodbujamo uvajanje novosti $\mathrm{v}$ izobraževanje. Na zavodu Doba smo prepričani, da se bo zaradi intenzivnega razvoja informacijske tehnologije in odprtosti do njene uporabe $\mathrm{v}$ praksi za izobraževanje »on-line« odločalo v Sloveniji vse več ljudi.

\section{IZVAJANIE POSAMEZNIH FAZ PROJEKTA}

Izvajanje posameznih faz projekta je potekalo v timu, v katerem je bil vsak strokovni delavec odgovoren za svoje področje. Faza postavitve mikroorganizacije študija na daljavo je zahtevala prilagoditev izvedbenega predmetnika za izvajanje programa Poslovni sekretar na daljavo. Pri nabavi in postavitvi strojne ter programske opreme za podporo študiju na daljavo smo dobivali informacije pri domačih računalniških podjetjih in tujih izobraževal- 
nih organizacijah, ki izvajajo izobraževanje na daljavo. Nabaviti je bilo treba zmogljiv strežnik in zagotoviti hitre povezave. Preizkusili smo programsko opremo za preoblikovanje učnih gradiv v elektronsko obliko in poenostavitev organizacije izvajanja študija »on-line«: od vzpostavljanja komunikacije s študenti, vključevanja samopreverjanj v študijski proces, jasnega pregleda nad individualnim delom študentov in njihovim delom $\mathrm{v}$ virtualni klepetalnici do vodenja statistike.

Priprava učnih gradiv za študij na daljavo je za vsako izobraževalno organizacijo velik izziv. Za potrebe tradicionalnega študija so pre-

Mentorji se
usposabljajo za
računalniško pod-
prto učenje in
tehnično komu-
nicijsko podporo
študentom.
davatelji naše višje šole že pripravili učno gradivo $\mathrm{z}$ elementi samostojnega učenja. Na podlagi evalvacije gradiva smo začeli postopoma preoblikovati gradivo v elektronsko obliko. Tudi faze svetovanja in usposabljanja za potrebe študija na daljavo se lotevamo postopoma. Zelo skrbno izbiramo mentorje, ki imajo po eni strani dovolj strokovno teoretičnega in praktičnega znanja, po drugi strani pa znajo motivirati študente in jih spodbujati pri študiju. Usposabljanje mentorjev poteka na področju metodike in didaktike računalniško podprtega učenja in tudi na področju tehnične podpore komunikacije $s$ študenti. Pri postavitvi administrativne podpore za potrebe študija na daljavo smo natančno opredelili tudi tehnično-informativno vlogo administrativnega kadra za študij na daljavo. $\mathrm{V}$ nadaljnjih fazah, na primer na področju promocije in evalvacije, načrtujemo sodelovanje pri programih Evropske unije.

\section{STROŠKI ZA RAZVOJ ŠTUDIJA NA DALJAVO}

Priprava in izvedba projekta študija na daljavo sta finančno zelo zahtevni, zato si v zavo- du Doba prizadevamo vsaj del sredstev pridobiti tudi iz drugih virov. Največji delež že od začetka zagotavlja zavod. Projekt oziroma posamezne faze projekta smo prijavili na razpise Ministrstva za šolstvo in šport, na Ministrstvu za delo, družino in socialne zadeve so nam nekaj finančnih sredstev dodelili na podlagi posebne vloge, uspešne so bile tudi naše prijave na razpise programov Evropske unije, na primer Leonardo da Vinci (septembra 1999 za izmenjave za inštruktorje, mentorje in tutorje ter marca $2000 \mathrm{za}$ pilotske projekte) in prijava na razpis nacionalne enote za razvoj študija na daljavo pri Ekonomski fakulteti $\mathrm{v}$ Ljubljani: program LOLA za organizatorje študija na daljavo (marca 1998).

V okviru priprav na izvajanje študija na daljavo smo se strokovni sodelavci zavoda Doba vključevali v različne oblike izobraževanja za organizacijo študija na daljavo (LOLA, How to Teach Adults, Online Teaching, LeTTOL) in $\mathrm{v}$ mednarodne programe izmenjav za organizatorje izobraževanj (Leonardo da Vinci). Sredstva Evropske unije so nam omogočila seznanitev s potekom študija na daljavo ter prenos znanja in tujih izkušenj v naš model, ki bo sodoben, fleksibilen in študentu prijazen.

\section{IZOBRAŽEVANJE NAŠIH STROKOVNIH SODELAVCEV V TUIINI}

a) LOLA (Learning about Open Learning). Ena od strokovnih sodelavk je v preteklem letu sodelovala pri programu, ki je potekal v okviru programa Phare, v Sloveniji pa je za koordinacijo izvedbe skrbela nacionalna enota za študij na daljavo pri Ekonomski fakulteti v Ljubljani, ki ima v Sloveniji z izvajanjem študija na daljavo največ izkušenj. V izobraževanje, ki je potekalo šest mesecev, je bilo vključenih 20 udeležencev iz Slovenije, iz različnih izobraževalnih ustanov (fa- 


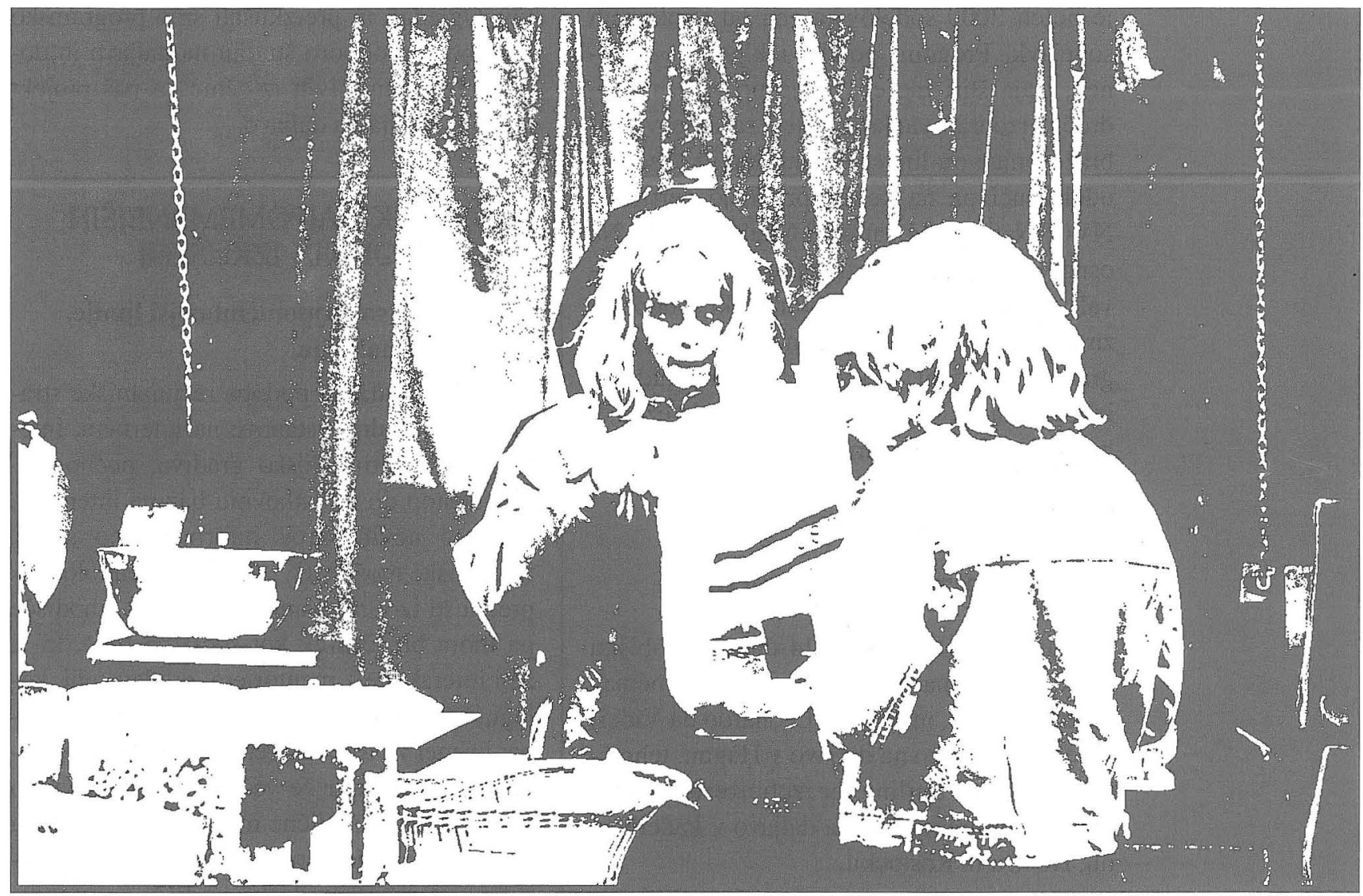

kultete, šole, zasebne ustanove, podjetja), ki so bili v skupino izbrani na podlagi razpisa. Hkrati je izobraževanje potekalo $\mathrm{v}$ enajstih državah v Evropi, vključenih pa je bilo približno 400 udeležencev. Naslov programa LOLA - Learning about Open Learning zajema osnovni cilj programa, to je udeležence seznaniti $\mathrm{z}$ načeli delovanja odprtega učenja. Večina izobraževanja je potekala »on-line«, torej prek interneta. Slovenska skupina udeležencev je komunicirala s tutorko s Škotskega. V primerjavi z drugimi državami se je zelo dobro odrezala, saj izobraževanja ni uspešno končal le eden od udeležencev. Tudi to je mogoče eden od pokazateljev, da smo pripravljeni na tako obliko izobraževanja, v katerega sta vključena sodobna tehnologija in internet.

b) DOBA je članica ameriške organizacije
LERN - Learning Resources Network, ki skrbi za povezovanje učnih virov in je ena od vodilnih organizacij za usposabljanje ter svetovanje na področju vseživljenjskega učenja. LERN organizira krajše seminarje in krajše oblike usposabljanja. Naši strokovni sodelavci se vključujejo predvsem v oblike izobraževanja, ki jih organizirajo »on-line«. Nabrali smo si že veliko novega znanja, izkušenj in tudi praktičnih veščin $\mathrm{v}$ zvezi $\mathrm{z}$ novimi ugotovitvami o značilnostih izobraževanja odraslih, izkušnjah drugih, ki delujejo na tem področju, in o izobraževanju »on-line«: kako deluje, njegove značilnosti, prednosti in tudi pomanjkljivosti, ki jih je treba pri izvajanju upoštevati.

c) LeTTOL (Learn to Teach On-line) je program usposabljanja na ustanovi Shefield College v Leedsu v Veliki Britaniji, pri katerem 
je poleti 2000 sodelovala ena od strokovnih sodelavk. Program poteka izključno »on-line $\ll$, traja štiri mesece in je priznan na področju izobraževanja tutorjev za delo v izobraževanju »on-line «, je zahteven in obsežen, udeleženci pa na koncu prejmejo certifikat NVQ (National Vocational Qualification). Na osnovi pridobljenega znanja bomo izobraževali in usposabljali mentorje, ki bodo na zavodu Doba v višješolskem strokovnem programu Poslovni sekretar vodili študente izobraževanja. Njihove študijske obveznosti bodo vezane predvsem na »on-line« komunikacijo in interakcijo.

\section{OBISKI NA TUIIIH USTANOVAH}

Februarja 2000 smo si na 14-dnevnem obisku v okviru mednarodnega programa izmenjav za inštruktorje, mentorje (Leonardo da Vinci) ogledali univerzo na daljavo v Hagnu, tehnično univerzo v Berlinu ter izobraževalne ustanove za izobraževanje na daljavo v Paderbornu, Höxtru in Rostocku.

Delovna področja obiska so bila didaktično-

\section{Ob vsem blišču} informacijske tehnologije ne kaže pozabiti, da je izhodišč clovek kot socialno bitje. metodični koncept učenja na daljavo, izobraževanje mentorjev, svetovanje in vodenje različnih skupin udeležencev izobraževanja na daljavo, merila za izbiro in pripravo multimedijskega gradiva ter organizacijski in tehnični pogoji za uporabo novih medijev.

Ogledali smo si snemalne studie, računalniški oddelek za razvijanje multimedijskega gradiva, prostor in opremo za uporabo video konferenčnega sistema, sodelovali smo pri pouku v virtualni učilnici, pogovarjali smo se $\mathrm{z}$ vodji študijskih središč, organizatorji in udeleženci izobraževanja na daljavo ter njihovimi mentorji. Za naše nadaljnje delo so bili koristni predvsem evalvacijski rezultati uspešnih mednarodnih projek- tov. Ogledali in preizkušali smo programsko opremo za podporo študiju na daljavo in dobili nekaj zanimivih iztočnic za naš projekt razvoja študija na daljavo.

\section{POVZETEK NAJPOMEMBNEJŠIH MEDNARODNIH IZKUŠENJ}

\section{a) Še vedno so najpomembnejši ljudje, in me tehnologija}

Zanimiva grafična podoba računalniške strani izobraževalne ustanove na internetu, interaktivno multimedijsko gradivo, poenostavljen dostop do podatkovnih baz na internetu, vse več novih virov informacij po svetu, tehnološke možnosti ... so samo »tehnološke « prednosti izobraževanja na daljavo, izhodišče pa mora biti človek kot socialno bitje, ki si želi interakcije z mentorjem, predavatelji, kolegi, če je možno, tudi v osebnem stiku. Dober primer za to je univerza na daljavo v nemškem Hagnu, kjer že več kot 25 let razvijajo in preizkušajo različne modele izobraževanja na daljavo. Začeli so z dopisnim izobraževanjem, ustanovili študijska središča po vsej državi in jih razširili tudi zunaj Nemčije. Ustanovili so svoj center za razvoj študija na dalja-

Pomen osebnih stikov v izobraževanju na daljavo so poudarjali tudi udeleženci in izvajalci različnih oblik izobraževanja na daljavo, s katerimi smo se pogovarjali med našim obiskom v Neměiji. $V_{s i}$ so si bili enotni, da so za svetovanje, motiviranje, dajanje povratmih informacij potrebni tudi osebni stiki in da te potrebe ne more zamenjati se tako dobro interaktivno nultimedijsko uěno gradivo oziroma programska oprema.

Ce torej želimo zagotoviti dostop do izobraževalnega programa čin širšemu krogu ludi, jim moramo omogočli srečanja tudi zunaj virtualnega prostora. 
vo, imeli so možnost, da $\mathrm{v}$ študij na daljavo uvedejo praktično vse novosti s področja izobraževalne tehnologije ... Zataknilo pa se je pri video konferenčnem sistemu. Študenti univerze na daljavo v Hagnu video konferenčnega sistema $v$ študiju niso sprejeli s takšnim navdušenjem, kot so ga pričakovali njegovi snovalci. Seminarske vaje so namreč izvajali prek video konferenčnega sistema. Študenti so hitro ugotovili, da nekaj manjka, pogrešali so osebno komunikacijo, pri seminarskih vajah jim je veliko bolj ustrezal stari način dela: srečanja $\mathrm{v}$ študijskih središčih, kjer so lahko $\mathrm{v}$ živo razpravljali s profesorji in kolegi, pri tem ni bilo treba čakati enkrat na sliko, drugič na ton, zato so lahko mnogo osebneje in produktivneje razpravljali o določeni problematiki. Video konferenčni sistem za izvajanje seminarskih vaj na univerzi na daljavo v Hagnu tako opuščajo in se vračajo $h$ klasičnemu načinu izvajanja seminarskih vaj - v živo v študijskih središčih.

\section{b) Izobraževanje na daljavo zahteva nov tip učitelja}

Če se želijo učitelji približati udeležencem izobraževanja na daljavo, morajo biti naklonjeni spremembam, ki jih prinašajo tehnološke novosti, pripravljeni učiti se, tudi na lastnih napakah. Udeleženci v virtualnem učnem prostoru reagirajo podobno kot udeleženci $\mathrm{v}$ klasičnem učnem prostoru. Če so predavanja dolgočasna, »zaspijo《. Razlika je v tem, da udeležence izobraževanja na daljavo veliko teže ponovno motiviramo oziroma animiramo, ker ni osebnega stika in lahko odnehajo. Udeleženci se ne zadovoljijo s kupi papirjev, na katerih je samo vsebina klasičnega predavanja, ki jo - namesto da bi si naredili zapiske pač natisnejo z interneta. Način posredovanja študijskih vsebin postaja vse pomembnejši. Avtor mora zelo dobro poznati svojo ciljno skupino, saj se v izobraževanju na daljavo zaradi prikazov praktičnih primerov, ki nadome- ščajo dodatne predavateljeve razlage na klasičnih predavanjih, še bolj izrazi generacijska in kulturna pogojenost pisanja gradiva. Izhodišče za pisanje gradiva je torej udeleženec. Dober avtor v gradivu za izobraževanje na daljavo $\mathrm{z}$ udeležencem ustvari dialog, $v$ dialogu spodbuja udeleženčevo zanimanje in kreativnost, v gradivo vključi primere, možnosti za samopreverjanje, jasne povzetke, ga oblikuje pregledno ter vizualno privlačno in udeleženca navaja $\mathrm{k}$ samostojnemu iskanju dodatnih virov ter zagotovi med izobraževanjem udeležencu podporo.

\section{c) Mentor ima v izobraževanju na daljavo zahtevnejšo vlogo}

Le dobro metodično-didaktično in tehnično usposobljen mentor, ki ima izkušnje z izobraževanjem na daljavo, ki zna in želi delati z ljudmi, lahko učinkovito pomaga udeležencem izobraževanja na daljavo: pri občutku izgubljenosti zaradi poplave informacij o študiju, pri dvomih v možnosti lastnega napredovanja in doseganja ciljev izobraževalnega programa, pri neza-

Mentor mora biti
dobro metodično,
didakticno in
tehnično podkovan.
upanju do tehnike, pa tudi pri tem, kako je treba ravnati $\mathrm{z}$ računalnikom in programsko opremo. Za udeleženca je namreč novo dvoje: sam izobraževalni program in način izvajanja. Pri tem potrebuje izčrpne informacije, vedno pa mora imeti občutek, da mu je mentor pri izobraževanju v oporo.

\section{č) Geografska oddaljenost ni več najpomembnejši razlog za odločitev za izobraževanje na daljavo}

Za izobraževanje na daljavo se odločajo večinoma odrasli, ki so zelo zaposleni in jim izobraževanje, tako kot otrokom in mladini, ni edina dejavnost, saj prevzemajo več socialnih vlog: so starši, zakonski partnerji, zaposle- 
ni ... Vse te vloge in z njimi povezane obveznosti zahtevajo od njih, da si drugače organizirajo čas. Osnovni razlogi za odločitev za izobraževanje na daljavo so večja samostojnost pri pridobivanju znanja, prilagajanje časa in tempa učenja lastnim obveznostim, pa tudi kakovostno študijsko gradivo, hitre in učinkovite povratne informacije, navsezadnje pa sprejemajo mnogi izobraževanje na daljavo tudi kot izziv (tudi Brečko, 1996).

\section{d) Pozitivne izkušnje izobraževanja na daljavo se hitro širijo na druga življenjska in delovna področja}

Kot najzanimivejše in področje, ki odpira veliko možnosti, naj omenimo delo na daljavo. Takšna organizacija in racionalizacija dela $v$ službi postaja alternativa vse večjemu številu ljudi, saj je na daljavo mogoče opravljati nekatera administrativna, razvojna in projektna dela.

\section{ŠTUDIJ NA DALJAVO NA ZAVODU DOBA}

Študij na daljavo, kot ga bomo izvajali na zavodu Doba, Višji strokovni šoli v Mariboru, bo prvi v celoti mulitmedijsko podprt študij na daljavo $v$ Sloveniji in je rezultat dela ter

Izmenjava mnenj med studenti bo možna tudi v virtualni klepetalnici. prizadevanj strokovnih delavcev na zavodu Doba. Eksperimentalno fazo bomo začeli izvajati v jeseni 2000.

Vpisni pogoji za študij na daljavo so enaki kot vpisni pogoji za tradicionalni način študija. Študij na daljavo po višješolskem strokovnem programu Poslovni sekretar je enakovreden drugim oblikam študija $\mathrm{v}$ tem programu (izobraževanje mladine, izobraževanje odraslih - tradicionalni študij).

Kandidati za študij na daljavo morajo izpolnjevati tudi druge pogoje. Imeti morajo multimedijski računalnik z ustrezno programsko opremo, tiskalnik, dostop do interneta in svoj elektronski naslov. Poznati morajo okolje Windows, obvladati delo z urejevalniki besedil in imeti lastno servisno podporo.

Letnik traja 18 mesecev, celotno izobraževanje pa tri leta. Pred začetkom izvajanja študija na daljavo bomo za študente izvedli poseben seminar o računalniško podprtem študiju.

Posamezen predmet bodo študenti študirali šest do devet tednov. Pred začetkom izvajanja posameznega predmeta bodo imeli uvodno srečanje s predavateljem, na katerem bo predavatelj predstavil cilje, vsebino predmeta in način dela ter mentorje. Učno gradivo bo študentom na voljo na naših spletnih straneh. $\mathrm{Na}$ začetku izvajanja predmeta bodo študenti prejeli tudi natančen urnik obveznosti, ki jih imajo pri posameznem predmetu.

Med študijem bo študentom na voljo mentor, ki bo odgovarjal na njihova vprašanja prek elektronske pošte in jim dajal povratne informacije. V virtualni klepetalnici bodo imeli študentje možnost medsebojne izmenjave mnenj in odgovorov na vprašanja. Študij ne bo v celoti »virtualen«, upoštevaje mednarodne izkušnje bodo študentje imeli možnost tudi za neposredne stike $\mathrm{z}$ mentorji, predavatelji ter s svojimi študijskimi kolegi v okviru tako imenovanih seminarskih srečanj.

\section{PRIHODNOST IZOBRAŽEVANIA NA DALJAVO}

Izobraževanje na daljavo ima vsekakor prihodnost tudi v Sloveniji. Še več: imamo enkratno priložnost, da uporabimo najpomembnejša znanja $v$ svetu in jih povežemo $z$ našim znanji in izkušnjami ter razvijemo takšne modele izobraževanja na daljavo, ki bodo dejansko usmerjeni k uporabniku. Tudi pri nas so (morebitni) udeleženci izobraževanja vse bolj sprejemljivi za izobraževanje »on-line« oziroma za izobraževanje na daljavo. Naloga nas izobraževalcev pa je, da z ustreznimi modeli 
Tudi razvoj v svetu kaže, da se bo koncept izobraževanja še naprej spreminjal v smeri uporabniku prijaznega načina izobraževanja, seveda le pod pogojem, da bomo pri tem upoštevali kakovostno interakcijo med študentom, predavateljem in učnim gradivom, in ne samo tehnoloskih inovacij. Americ Azevedo, ameriski strokovnjak na področju izobraževanja na daljavo, v svoji predstavitvi metode $» 0 n-l i n e \ll v$ programu Socrates namreě meni: »Ne učijo računalniki, učijo ljudje.«

izobraževanja na daljavo udeležencem omogočimo doseganje enakih ciljev po drugi poti in spodbujamo njihovo zanimanje ter tako na splošno promoviramo izobraževanje.

Na zavodu Doba smo in še bomo v izvedbo projekta izobraževanja na daljavo vložili veliko strokovnega dela, tudi v okviru mednarodnega povezovanja in sodelovanja. Verjamemo, da bodo spremljanje svetovnega razvoja v izobraževanju na daljavo, lastne izkušnje na tem področju in tesnejše sodelovanje s sorodnimi ustanovami v tujini, zlasti pri izmenjavi izkušenj in znanja, našemu modelu študija na daljavo vnesli evropsko razsežnost, da bo primerljiv z najsodobnejšimi in najučinkovitejšimi modeli v Evropi ter da bodo naši študentje za izobraževanje na daljavo med najuspešnejšimi.

Mateja Geder

Ema Perme

\section{LITERATURA}

Ballstaedt, S. P. in drugi (1995). Planung, Entwicklung, Durchführung von Fernstudienangeboten: Eine Handreichung. Tübingen: Deutsches Institut für Fernstudienforschung an der Universität Tübingen.

Bregar, L. (1998). Strateška vprašanja nadaljnjega razvoja študija na daljavo v Sloveniji, VIZ, 3, str. 4-13.
Brečko, D. (1996). Motivacija pri izobraževanju na daljavo. Andragoška spoznanja 1, str. 22-32.

Bregar, L. (1998). Študij na daljavo na Ekonomski fakulteti, VIZ, 3, str. 14-20.

Draves, W. A. (1998). How to Teach Adults, LERN, ZDA.

Owston, R. D. (1997). The World Wide Web: A Technology to Enhance Teaching and Learning? Educational Researcher, Vol. 26, 2, str. 27-33.

\section{VIRI}

http://wwww.lern.org/draves/works/internet_change_report.htm

http://www.goldwarp.com/essays/teaching.htm http://www.frstmonday.dk/issues3_1/noble/index.html 